\title{
THE LOWER TORSO OF A GRANITE ROYAL STATUE FROM DUWEYM WAD HAJ ${ }^{1}$
}

\author{
Květa SMOLÁRIKOVÁ \\ Aigyptos Foundation \\ Šafárikova 63, 95197 Žitavany \\ kveta.smolarikova@ff.cuni.cz \\ Jozef HUDEC \\ Institure of Oriental Studies, Slovak Academy of Sciences \\ Klemensova 19, 81364 Bratislava \\ jozef.hudec@savba.sk
}

\begin{abstract}
This contribution deals with the discovery of the torso of a royal statue in Duweym Wad Haj. The site might have a significant position on the route between Gebel Barkal and Meroe, via the Bayuda Desert. During the 2019 season the lower part of a seated life-size statue was discovered there by a survey. It represents a king wearing a short royal shendyt kilt, seated on a throne/chair of a rectangular shape. Its left side is concave and without decoration, the right one is broken. There is no inscription on the back pillar, because the statue was only roughly hewn in this part. It seems that the statue remained unfinished owing to a crack in the stone material. It is possible to presume that a sculpture workshop may have existed on the Duweym site during the Kushite period. However, it is also possible that the stone material was brought to Duweym from other sites, such as Sanam, Ghazali or Gebel Barkal.
\end{abstract}

Keywords: Duweym Wad Haj, statue, granite, king, Kush

The site of Duweym Wad Haj is located about $350 \mathrm{~km}$ north of Khartoum, in the Great Bend of the river Nile on its left bank, opposite (across the river) Gebel Barkal - one of the most significant Sudanese ancient sites.

Duweym was identified by Faiz Hassan Osman, a graduate of Karima University. Timothy Kendall, the co-director of the NCAM Gebel Barkal

1 The article originated within the project APVV-17-0579 Slovak Research at the Sudanese Site of Duweym Wad Haj. 
Mission, visited Duweym during a field trip on February 11, 2005. ${ }^{2}$ Based on information about blocks of red sandstone and black granite (Fig. 1), and the possibility of a buried ancient temple (?), run on Kendall's website ${ }^{3}$, Jozef Hudec visited the site on November 18, 2017 and did a reconnaissance. The presence of red sandstone and black granite blocks was confirmed, and also a dressed black granite stone block (with niches or stairs?) had been set up in front of the left side of the western entrance to the old mosque ${ }^{4}$ (Fig. 2).

These blocks were outside the scope of the Slovak mission's objectives during the geophysical GPR survey of the site in February 2018. However, fragments of other imported stones - red granite and alabaster - were discovered. ${ }^{5}$

The season in January and February 2019 also focused its survey activities on the black granite blocks. The dressed block to the left side of the western entrance to the old mosque was cleaned and examined. ${ }^{6}$ It turned out to be the fragmentary, surviving lower part of a finely carved life-size seated statue (Fig. $3 \mathrm{a}-\mathrm{c}$ ). It is about $90 \mathrm{~cm}$ high, including the base. As a whole it is heavily damaged and the upper part of the body as well as the head are missing.

The male (king) figure wears a rather deeply grooved short royal shendyt kilt $^{7}$, which is clearly visible on the right part of the statue, ${ }^{8}$ whereas the characteristic central tab as well as the left thigh were broken off. Although the surface of the king's legs has also suffered extensive damage, enough of his feet are preserved to show their 'mummy-form' shape', which indicates that they were not finished, even the in-fill between the feet was not cut away, as was

\footnotetext{
${ }^{2}$ Personal e-mail communication from January 27 and January 28, 2020.

${ }^{3}$ KENDALL, T. Jebel Barkal History and Archaeology of Ancient Napata [online] [cit. 4 February 2019]. Available from http://jebelbarkal.org/index.php?option=com_content $\&$ view $=$ article $\&$ id $=67 \&$ Itemid $=77$.

${ }^{4}$ HUDEC, J., CHEBEN, M., KOVÁR, B. Report on Surveys in Duweym Wad Haj. In Asian and African Studies, 2019, Vol. 28, No. 2, pp. 170-171.

${ }^{5}$ HUDEC, J., CHEBEN, M., KOVÁR, B. Report on Surveys in Duweym Wad Haj. In Asian and African Studies, 2019, Vol. 28, No. 2, p. 177 (fig. 21, p. 428).

${ }^{6}$ HUDEC, J., KOVÁR, B., FULAJTÁR, E., LIESKOVSKÝ, T., HORÁKOVÁ, L., ČERNÝ, M., BARTA, P. A Brief Report on the 2019 Season in Duweym Wad Haj. In Asian and African Studies, 2021, Vol. 30, No. 1, p. 213.

${ }^{7}$ RUSSMANN, E. R. The Representation of the King in the XXVth Dynasty, p. 25.

${ }^{8}$ This clearly indicates that his right hand was not placed on his right thigh.

${ }^{9}$ This shape is typical for the gods Osiris and Ptah, but they do not wear the shendyt kilt, cf. BOTHMER, B., DE MEULENAERE, H., MÜLLER, H.-W. Egyptian Sculpture of the Late Period, 700 BC to AD 100, Pl. 38; WELSBY, D. A. Kawa. In WELSBY, D. A., ANDERSON, J. A. Sudan. Ancient Treasures, p. 154, fig. 136.
} 
usual. ${ }^{10}$ A hint that the sculptor started the intended work is the fact that on the left side a small part of his heel is clearly visible.

Generally, the modelling of the body seems to be symmetrical and emphasizes the king's muscular legs. He is seated on a throne/chair of rectangular shape; whereas the left side is concave and without decoration the right side is broken. There is no inscription on the back (back pillar); on the contrary, it seems certain that this part of statue was only roughly hewn, thus, its real treatment never started, and chisel traces are apparent on the surface.

Although it is not easy to discuss the iconography of this statue on the basis of such poor remains, with regard to the posture of the statue's arms, it seems that the right is held across the chest and the left perhaps resting on the thigh or also held across the chest. ${ }^{11}$ The figure may be holding a sceptre in his right (and left?) hand. Thus our torso of black granite may representing a seated king.

\section{Royal Iconography}

Although the Kushite kings of the 25th Dynasty were foreigners in Egypt, this ethnic group was already well-known to Egyptian artisans and consequently their depictions show them in the main as traditional Egyptian rulers, with just a few elements that set them apart from other kings. The close-fitting cap crown, is worn with a wide headband, decorated around the top with a row of uraei. ${ }^{12}$ In the majority, they wear a short pleated kilt, the so-called shendyt. During the Third Intermediate Period there dominated all around a trend in which striding and kneeling postures were much preferred to seated ones as is indicated by a series of cachettes discovered in the Amun temple at Napata ${ }^{13}$ and in the Amun

10 For comparison see the seated statue of the high New Kingdom dignitary Hekaemsasen, now housed in the Sudan National Museum, Khartoum. In DAVIES, V. The British Museum Epigraphic Survey at Tombos: the Stela of Usersatet and Hekaemsasen. Sudan \& Nubia, 2009, No. 13, p. 25, P1. 3.

11 BONNET, C., VALBELlE, D. Des pharaons venus d'Afrique. La cachette de Kerma. Paris, 2005, p. 171, where the headless seated statue of the king Aramatelko is depicted.

12 RUSSMANN, E. R. 'Some Reflections on the Regalia of the Kushite Kings of Egypt.' In Meroitica, 1979, 5, pp. 49-51.

${ }_{13}$ DUNHAM, D. The Barkal Temples, Excavated by George Andrew Reisner, Pls. IXXIII. 
temple of Dokki Gel (Kerma/Pnubs). ${ }^{14}$ Most statues seems to have been made for temples. ${ }^{15}$

Interesting and significant observations were made during the cleaning of the surface of the statue under discussion. In the lower part of the statue's legs about its knee - a long bad vertical crack is clearly visible. It is certainly not a fresh break; on the contrary, it seems that the ancient craftsmen had already noticed it and thus the statue was never finished but simply abandoned, ${ }^{16}$ as indicated not only by the unfinished feet but especially by the rough surface of the back pillar, usually covered with hieroglyphic inscription. Recently also $\mathrm{T}$. Kendall has discussed the colossal unfinished cracked statue of Senkamanisken, which was simply left and abandoned in the Tombos granite quarry. ${ }^{17}$

Can this mean hypothetically that the statue might come from a sculptor's workshop which was active during the Kushite (Napatan or Meroitic) period somewhere at Duweym Wad Haj, similar to those which are depicted on the walls of the noblemen from Thebes, ${ }^{18}$ for example? So far there is no supporting evidence. No other fragments, no heaps of black granite chips have been discovered so far.

Nevertheless, according to Kendall, Duweym is the site where an ancient temple might be situated ${ }^{19}$, directly across the river Nile from Gebel Barkal, and such a cultic institution also would have need statues.

It is not without interest that the western entrance to the mosque is flanked by two large cubes of black granite (Fig. 4), obviously ancient, which were evidently reused here. It is of course, impossible to be sure, so far, that they come from the same ancient source/site as the statue discussed, but this idea is very tempting. A site like this would have been closely linked to the religious

14 BONNET, C., VALBELLE, D. Des pharaons venus d'Afrique. La cachette de Kerma, pp. 70-118.

${ }^{15}$ Generally discussion focuses on the typology and character of Egyptian sculpture during the first millennium BC. Cf. ROBINS, G. The Art of Ancient Egypt, p. 225.

${ }^{16}$ This act was not exceptional, as the famous cracked 'unfinished obelisk' in the Aswan quarries shows, cf. SAMPEL, B. M. A Traveller's Guide to the Geology of Egypt, p. 61.

17 KENDALL. T. Reused Relief Blocks of Piankhy from B 900: Toward a Decipherment of the Osiris Cult at Gebel Barkal. In ANDERSON, J. R., WELSBY, D. A. (eds.). The Fourth Cataract and Beyond. Proceedings of the 12th International Conference for Nubian Studies, p. 683, Pl. 15a-b.

${ }^{18}$ Ibid., p. 28, figs. 21, 22.

${ }^{19}$ KENDALL, T. Jebel Barkal History and Archaeology of Ancient Napata [online] [cit. 4 February 2019]. Available from http://jebelbarkal.org/index.php?option=com_content $\&$ view $=$ article $\&$ id=67\&Itemid $=77$. 
centre of Gebel Barkal ${ }^{20}$ with its numerous temples, the more so since it lies directly at the heart of the Kushite kingdom: el-Kurru, Nuri, and Sanam are situated nearby. ${ }^{21}$ It is widely known (see the discussion below) that many statues were brought to the Kushite temples from older, mostly New Kingdom's sites, but it seems irrational to move an unfinished one.

One can imagine that there was here at least a strategically situated ford or ferry between Gebel Barkal on the northern bank and a site on the southern riverbank, which connected Napata to and from Meroe, about $280 \mathrm{~km}$ across the Bayuda Desert to the southeast, via the Wadi Abu Dom road. ${ }^{22}$

\section{Discussion}

Already Piankhy/Piye after his military campaign had without doubt brought from Egypt some architects and sculptors who could make large statues for the temple of Amon at Gebel Barkal. ${ }^{23}$ However, at that time, the most spectacular pieces came from the older temples of Nubia. Another powerful Kushite king and his son Taharko $(690-664$ BC) set up at this temple a series of fine statues made by Egyptian sculptors, who had executed the best of the earlier Kushite reliefs and statues. ${ }^{24}$ Here a colossal black granite statue was erected, perhaps in the first court. Some $4.18 \mathrm{~m}$ high, the king is shown wearing the tall, fourplumed crown of the god Onuris. This image, discovered along with a number of other broken royal statues buried outside the great temple, served as the model for Kushite royal statues for the next hundred years. ${ }^{25}$ Excellent proof of this can be found at Dangeil, a site located about $50 \mathrm{~km}$ above the Fifth Cataract, ${ }^{26}$ where in the debris of the temple of Amon from the 1st century AD numerous fragmentary royal statues were discovered. They represented several important Napatan rulers: Taharko (690 - 664 BC), Senkamanisken (643 - 623 BC) and perhaps Aspelta (c. $593-568$ BC), and the statue of a seated late

${ }^{20}$ KENDAL, T. Jebel Barkal. In WELSBY, D. A., ANDERSON, J. A. Sudan. Ancient Treasures, pp. 158-164.

${ }^{21}$ EDWARDS, D. N. The Nubian Past. An Archaeology of the Sudan, pp. 112-140.

${ }^{22}$ KENDALL, T. Jebel Barkal History and Archaeology of Ancient Napata [online] [cit. 4 February 2019]. Available from http://jebelbarkal.org/Aneighboring-archaeologicalsites.

${ }^{23}$ MORKOT, R. G. The Black Pharaohs. Egypt's Nubian Rulers, p. 197.

${ }^{24}$ SMITH, W. S. The Art and Architecture of Ancient Egypt, pp. 395-400.

${ }^{25}$ MORKOT, R. G. The Black Pharaohs. Egypt's Nubian Rulers, p. 257.

${ }^{26}$ ANDERSON, J. R., SALEH ELDIN, M. A. What are these doing here above the Fifth Cataract?!! Napatan royal statues at Dangeil. In Sudan \& Nubia, 2009, No. 13, pp. 78-98. 
Kushite Meroitic lady. The excavators suppose that this Meroitic temple was founded directly upon an earlier mud-brick temple dated to the Napatan era and the Napatan royal statutes were originally carved for and erected in such a temple of Amon at Dangeil.

It is evident that the most impressive achievements of the artists of the 25th Kushite dynasty were their royal statues, produced by Egyptian sculptors who were for the first time working fairly extensively under the rule of foreign pharaohs. ${ }^{27}$ Speaking about Egypt, the statues of fine hard stone were in majority found at Memphis and at Thebes, where their ambitious building programmes were realized. ${ }^{28}$ Especially, then, at Thebes they had been longestablished. However, smaller programmes are known also from sites across the country. The mineral sources for such ambitious activities were almost unlimited. One of the most important granite quarries was near Aswan and it has been proved that they supplied the Kushite kings as well. The granite rocks of the First Cataract south of the city have numerous visible quarrying marks in many places, and the quarry area extends some $6 \mathrm{~km}$ east of the city as well. ${ }^{29}$

An impressive body of literature has grown up around Taharko's building programme in Nubia where he initiated numerous large temples including a new temple at Sanam, ${ }^{30}$ opposite the royal cemetery of el-Kurru and a few kilometres downstream from Gebel Barkal and Duweym. Rather poor remnants of other buildings of this period show that it must have been an important town. The large temple was dedicated to Amun-the-Bull, Lord of Nubia. ${ }^{31}$ Built on local soft sandstone, the remains have not survived in a good condition. The long foundation text records that ships brought a collection of statues from the island of Shaat/Sai, which is the site of a New Kingdom fortress and temples. Evidently the temples were long ago stripped of their sumptuous decoration, including statues. Taharqo equipped his temples with monuments from older, now ruined and/or disused, pharaonic shrines, just as his father Piankhy had done at Gebel Barkal. Indeed, from Sanam came a piece of a seated statue, originally of Amenhotep III, which had been re-inscribed for Piankhy. ${ }^{32}$

Duweim Wad Haj lies about $4 \mathrm{~km}$ nearby Sanam and is still a terra incognita for archaeologists and historians respectively, since no long-term

\footnotetext{
${ }^{27}$ MALEK, J. Egyptian Art, p. 359.

${ }^{28}$ MORKOT, R. G. The Black Pharaohs. Egypt's Nubian Rulers, pp. 197-292.

${ }^{29}$ BAINS, J., MALEK, J. Atlas of Ancient Egypt, pp. 20, 72-73.

${ }^{30}$ POPE, J. The Double Kingdom under Taharko. Studies in the History of Kush and Egypt, c. $690-664$ BC, pp. 58-145.

${ }^{31}$ GRIFFITH, F. L. Oxford excavations in Nubia. In Liverpool Annals of Archaeology and Anthropology, 1922, Vol. 9, pp. 67-124.

${ }^{32}$ Ibid., Pl. XV.
} 
scientific research has yet been undertaken here. In any case, it was located within the immediate orbit of the main cultic core at Gebel Barkal. Bearing in mind all these facts; it is quite understandable that the crucial question of the provenance of our statue remains so far unanswered. As a first step, a thorough survey of the highly promising areas of Duweym is needed, which could clarify the possible character of the site, hopefully revealing a temple and workshop. It is appropriate to note at this juncture that numerous written sources prove that there were constant and quite intensive exchanges between the main centres of Kushite power in Egypt and those in Nubia. Craftsmen, sculptors and a wide range of other specialists were sent from pharaonic Egypt to work on the magnificent decoration of many new temple complexes in Upper Nubia, ${ }^{33}$ thus stimulating significantly the production and distinctive style of the Kushite sculptors' workshops. ${ }^{34}$

This is just a tentative hypothesis based on the torso of a badly damaged black granite statue. One wonders what is behind its occurrence at a site like Duweym Wad Haj; whether it might come from other, nearby temples at Gebel Barkal or Sanam, ${ }^{35}$ the Ghazali site, or whether it is an abandoned piece from a local sculptor's workshop. Work on the site leads us to believe that in future this puzzle will be successfully solved.

\section{REFERENCES}

ANDERSON, Julie R., SALEH ELDIN, Mohamed Ahmed. What are these doing here above the Fifth Cataract?!! Napatan royal statues at Dangeil. In Sudan \& Nubia, 2009, Vol. 13, pp. 78-86.

BAINS, John, MALEK, Jaromir. Atlas of Ancient Egypt. London: Phaidon, 1989.

BONNET, Charles, VALBELLE, Dominique. Des pharaons venus d'Afrique. La cachette de Kerma. Paris, 2005.

${ }^{33}$ In this context it is worth noting that craftsmen from Memphis were employed by Taharko at Kawa, cf. RUSSMANN, E. The Representation of the King in the XXVth Dynasty, p. 22.

${ }^{34}$ MYSLIWIEC, K. Royal Portraiture of the Dynasties XXI-XXX, pp. 39-45; here the author meticulously discusses the development and iconographic records of the most important centres of Kushite presence: Napata and Thebes for reliefs and Kawa for statuary.

${ }^{35}$ HUDEC, J., KOVAR, B., CHEBEN, M. Report on Survey in Duweym Wad Haj. Interim, unpublished report, pp. 13. 
BOTHMER von, Bernard, DE MEULENAERE, Herman, MULLER, HansWolfgang. Egyptian Sculpture of the Late Period, 700 BC to AD 100. Brooklyn, New York, 1960.

DUNHAM, Dows. The Barkal Temples, Excavated by George Andrew Reisner. Boston, 1970.

DAVIES, Vivian. The British Museum epigraphic survey at Tombos: the stela of Usersatet and Hekaemsasen. In Sudan \& Nubia, 2009, Vol. 13, pp.17-29.

EDWARDS, David N. The Nubian Past. An Archaeology of the Sudan. London and New York, 2004.

GRIFFITH, Francis Llewellyn. Oxford excavations in Nubia. In Liverpool Annals of Archaeology and Anthropology, 1922, Vol. 9, pp. 67-124.

HUDEC, Jozef, KOVAR, Branislav, CHEBEN, Michal. Report on survey in Duweym Wad Haj. Interim, unpublished report, Bratislava, 2018, pp. 1-13.

HUDEC, Jozef, CHEBEN, Michal, KOVAR, Branislav. Report on surveys in Duweym Wad Haj. In Asian and African Studies, Vol. 28, No. 2, 2019, pp. 168-179 (figures pp. 418-428).

HUDEC, Jozef, KOVÁR, Branislav, FULAJTÁR, Emil, LIESKOVSKÝ, Tibor, HORÁKOVÁ, Lenka, ČERNÝ, Miroslav, BARTA, Peter. A Brief Report on the 2019 Season in Duweym Wad Haj. In Asian and African Studies, 2021, Vol. 30, No. 1, pp. 202-224 (figures pp. 254-272). DOI: 10.31577/aassav. 2021.30.1.10

KENDALL, Timothy. Jebel Barkal. In WELSBY, D. A., ANDERSON, Julie A. Sudan. Ancient Treasures. London: The British Museum, 2004. pp. 158-164.

KENDALL, Timothy. Jebel Barkal. History and Archaeology of Ancient Napata. 2010 [online] [cit. 4 February 2019]. Available from http://jebelbarkal.org

MALEK, Jaromír. Egyptian Art. London: Phaidon, 1999.

MORKOT, Robert G. The Black Pharaohs. Egypt's Nubian Rulers. London, 2000.

MYSLIWIEC, Karol. Royal Portraiture of the Dynasties XXI - XXX. Main am Rhein, 1988.

POPE, Jeremy. The Double Kingdom under Taharko. Studies in the History of Kush and Egypt, c. 690 - 664 BC. Leiden Boston, 2014.

ROBINS, Gay. The Art of Ancient Egypt. Cairo, The American University Cairo Press, 2008.

RUSSMANN, Edna D. The Representation of the King in the XXVth Dynasty. Brussels, Brooklyn and New York, 1974.

RUSSMANN, Edna D. Some Reflections on the Regalia of the Kushite Kings of Egypt. In Meroitica, 1979, Vol. 5, pp. 49-51.

SAMPEL, Bonnie M. A Traveller's Guide to the Geology of Egypt. Cairo, 2003. SMITH, Stevenson W. The Art and Architecture of Ancient Egypt. Yale University Press, 1981. 


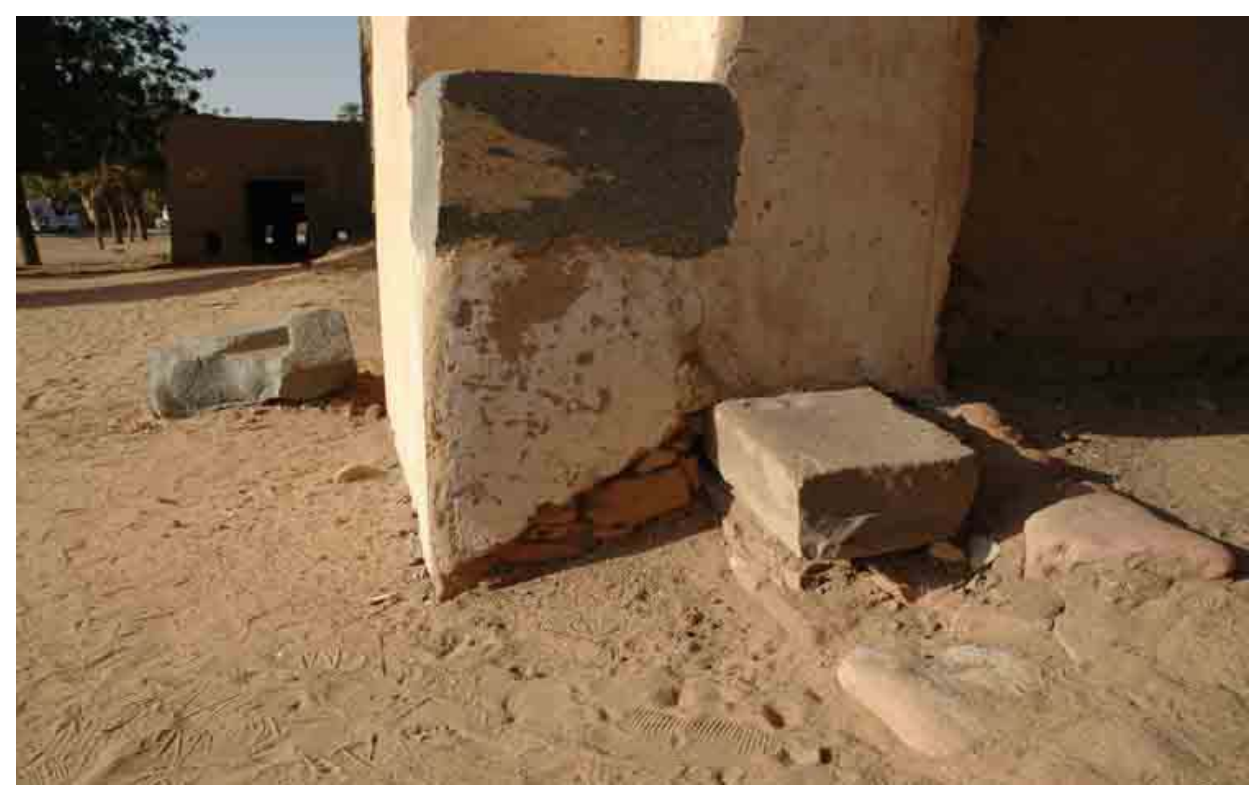

Hudec, Fig. 1. Blocks of pink sandstone and black granite in 2005 (Photo: Courtesy of Timothy Kendall)

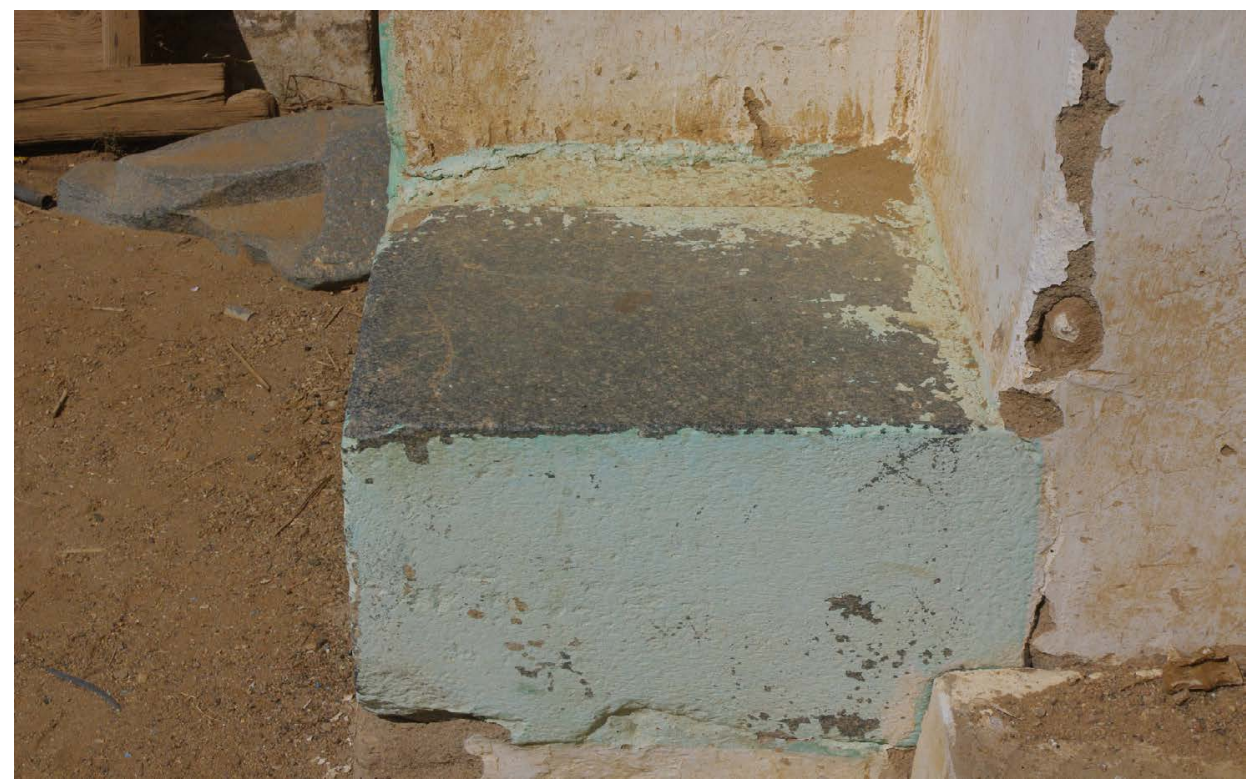

Hudec, Fig. 2. Dressed black granite blocks in front of the entrance to the old mosque in 2017 (Photo: Jozef Hudec) 
Asian and African Studies, Volume 30, Number 2, 2021
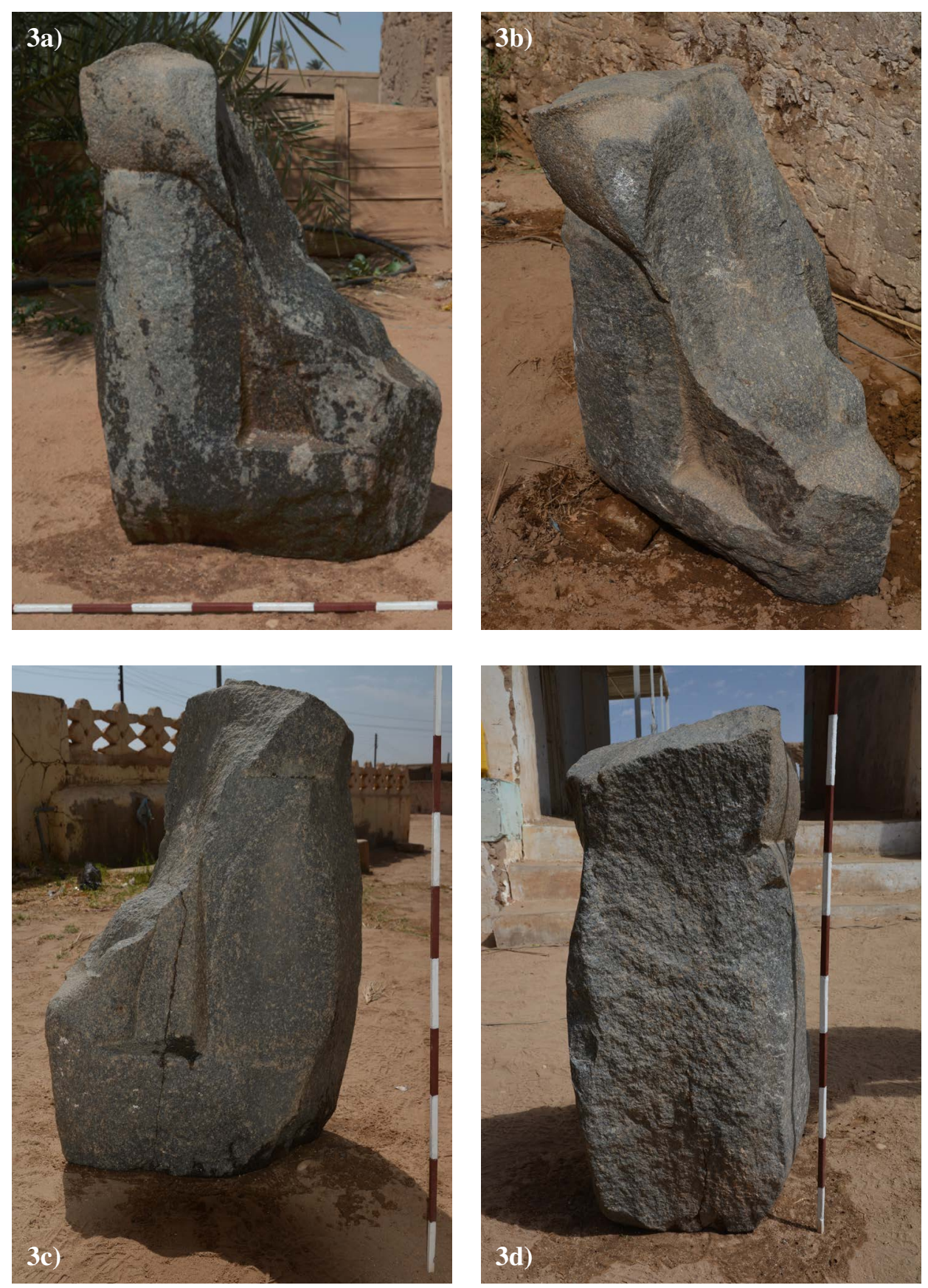


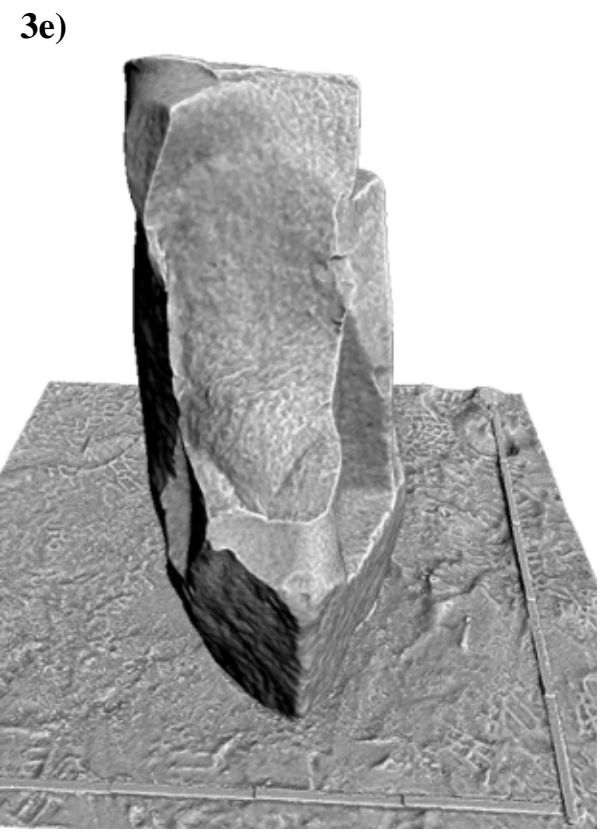

Hudec, Fig. 3 a-e. Lower part of seated life-size statue in 2019 (Photo: Jozef Hudec, Kveta Smoláriková, Tibor Lieskovský)

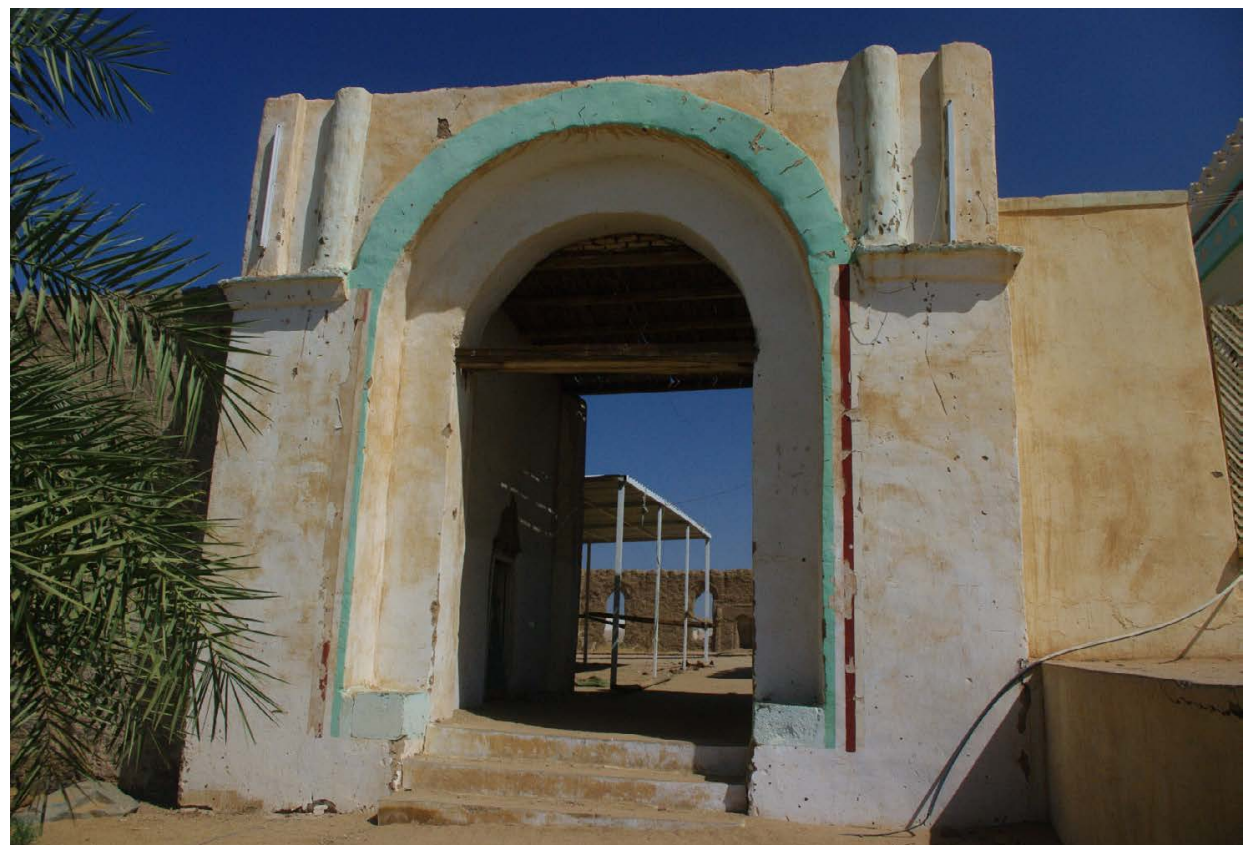

Hudec, Fig. 4. Western entrance to the old mosque flanked by two cubes of black granite in 2017 (Photo: Jozef Hudec) 


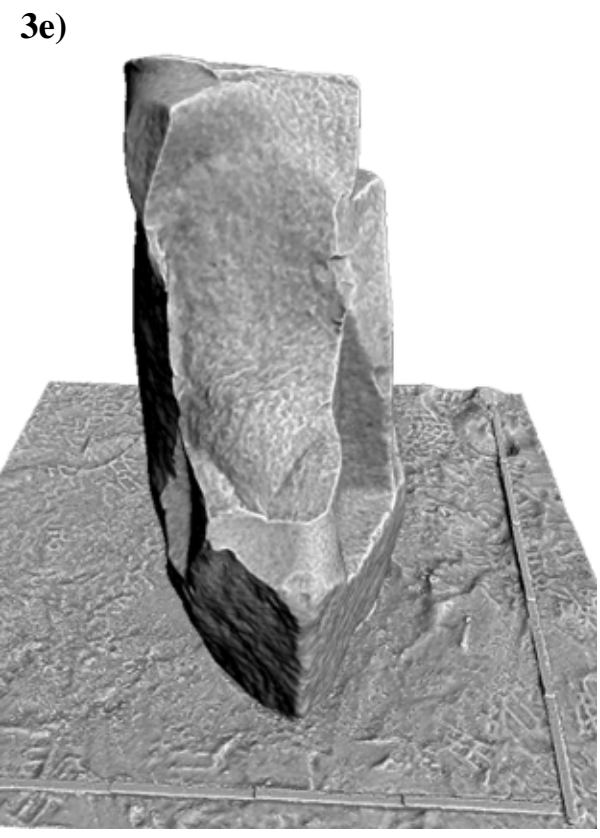

Hudec, Fig. 3 a-e. Lower part of seated life-size statue in 2019 (Photo: Jozef Hudec, Kveta Smoláriková, Tibor Lieskovský)

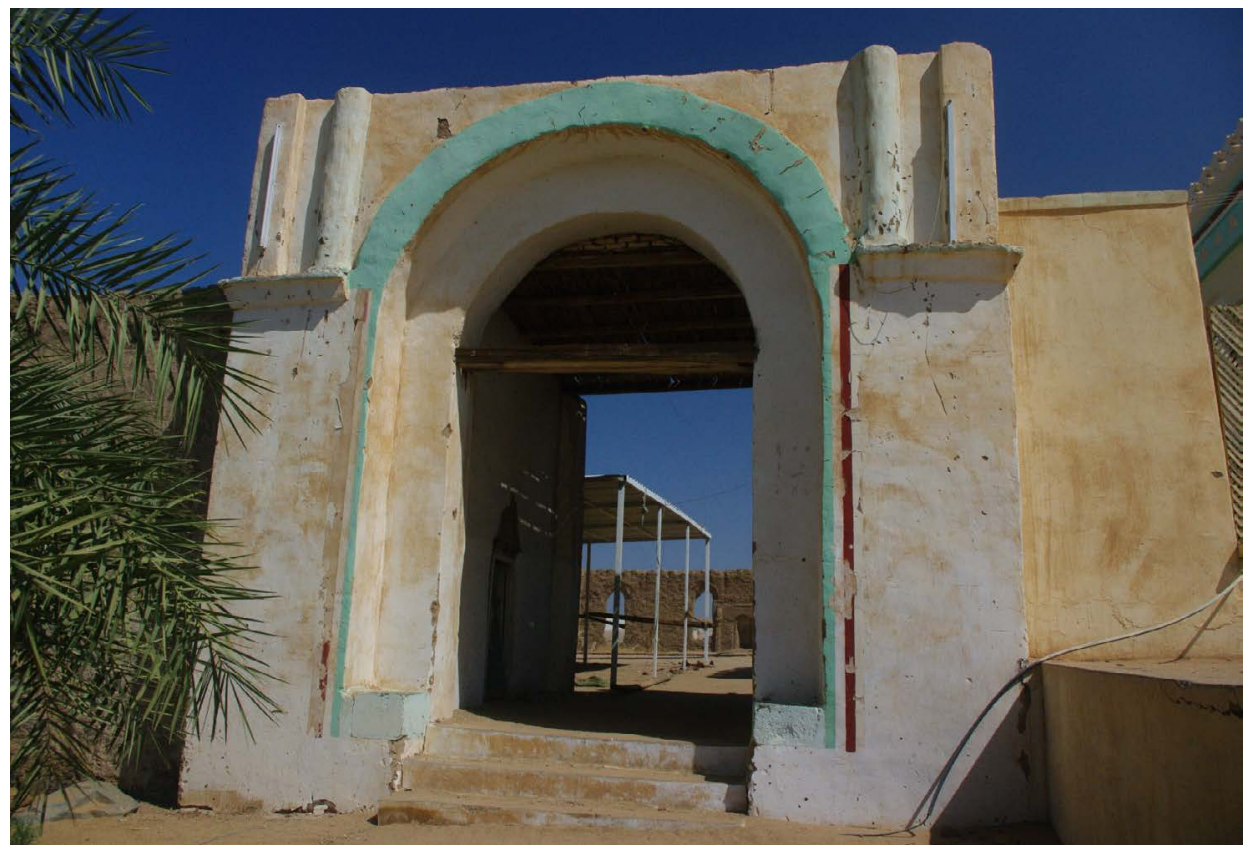

Hudec, Fig. 4. Western entrance to the old mosque flanked by two cubes of black granite in 2017 (Photo: Jozef Hudec) 
Asian and African Studies, Volume 30, Number 2, 2021
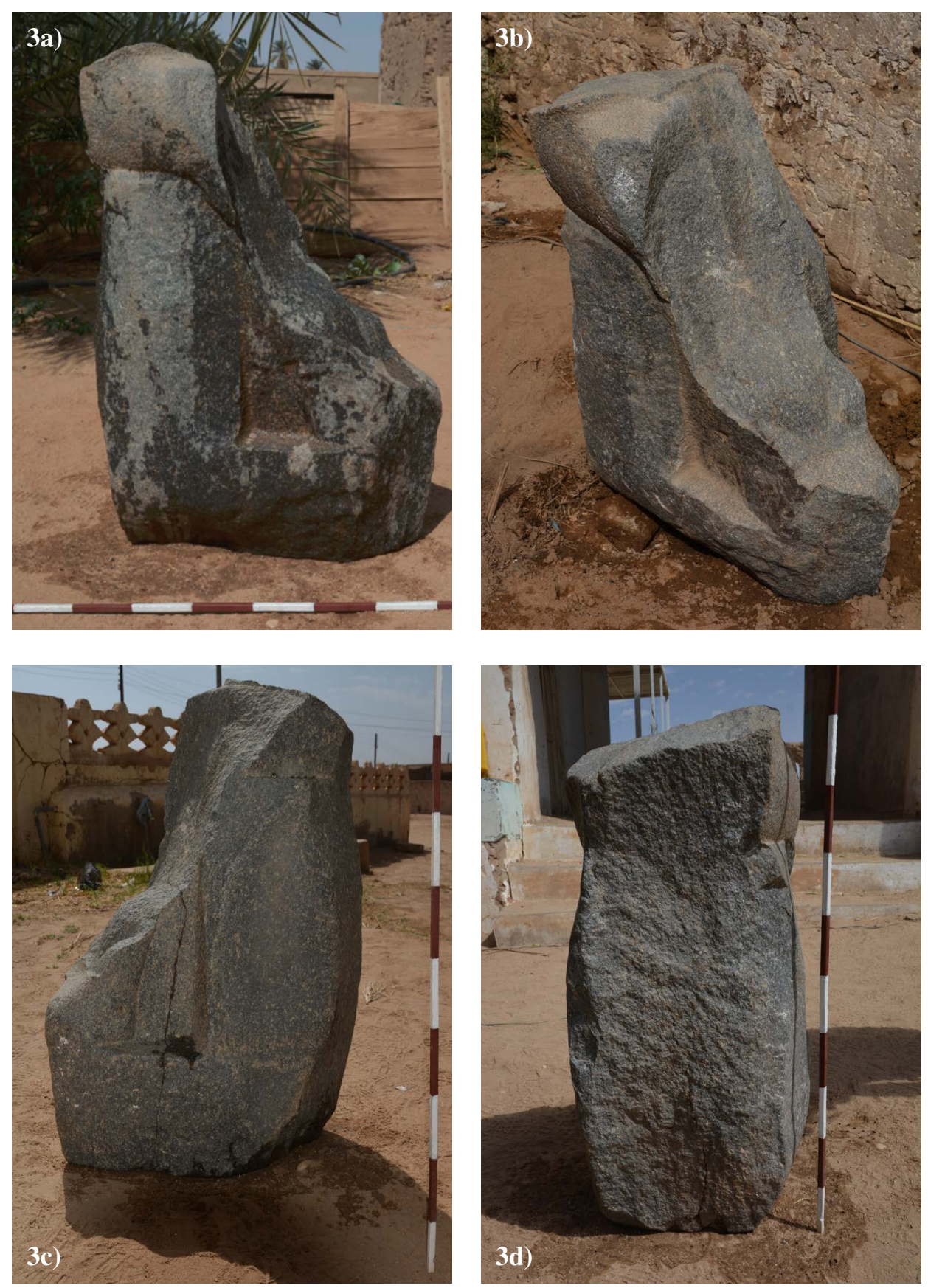


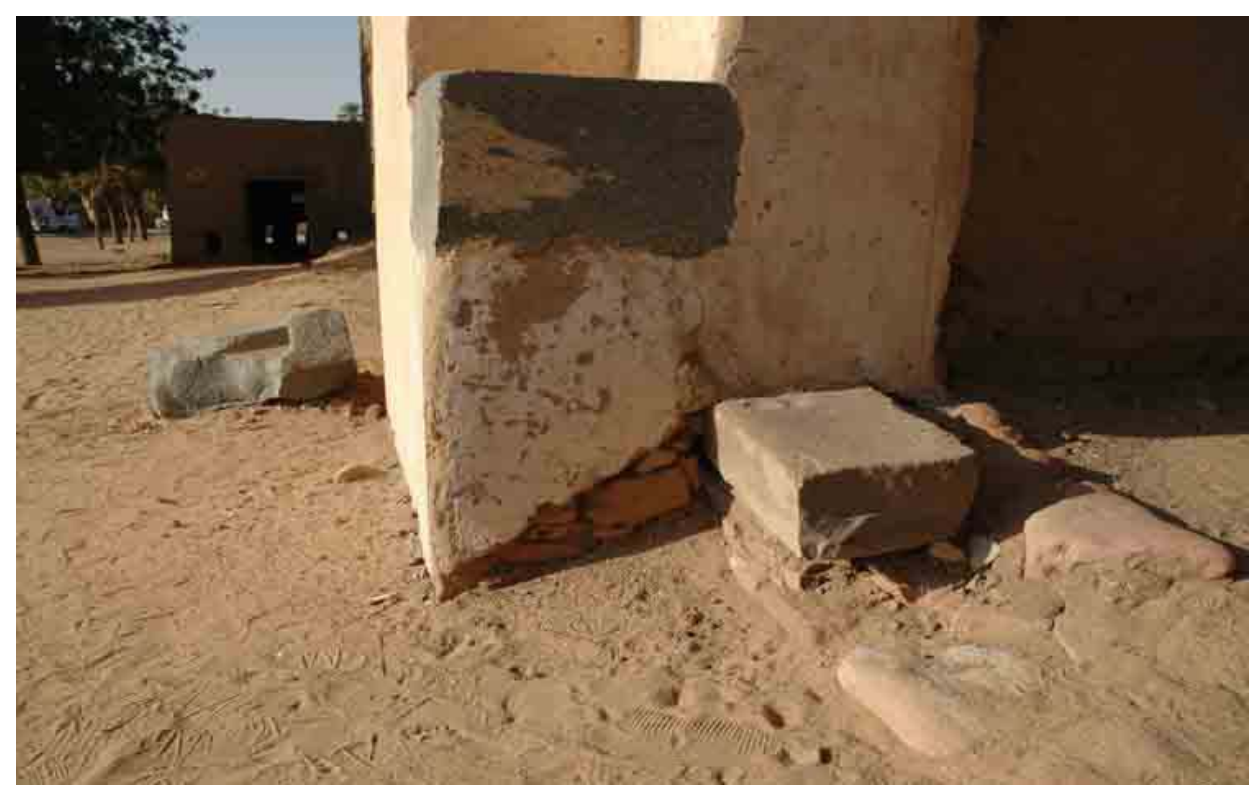

Hudec, Fig. 1. Blocks of pink sandstone and black granite in 2005 (Photo: Courtesy of Timothy Kendall)

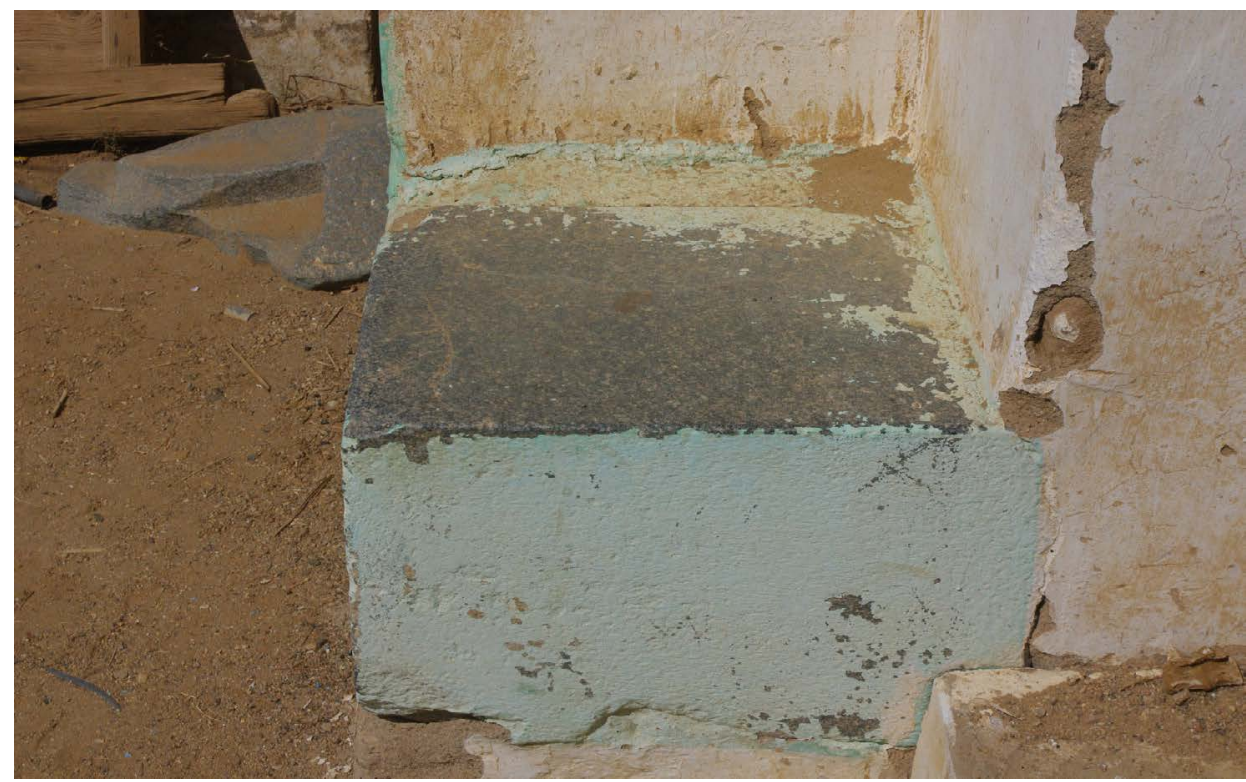

Hudec, Fig. 2. Dressed black granite blocks in front of the entrance to the old mosque in 2017 (Photo: Jozef Hudec) 